\title{
Application Design on Islamic Online Learning
}

\author{
$1^{\text {st }}$ A M Bachtiar \\ Departemen Teknik Informatika \\ Universitas Komputer Indonesia \\ Jl. Dipati Ukur No.112-116, \\ Lebakgede, Kecamatan Coblong, Kota \\ Bandung, Jawa Barat 40132, Indonesia \\ andi.rifiana@civitas.unas.ac.id
}

\author{
$2^{\text {nd }} M$ A Matin \\ Departemen Teknik dan Ilmu Komputer \\ Universitas Komputer Indonesia \\ J1. Dipati Ukur No.112-116, \\ Lebakgede, Kecamatan Coblong, Kota \\ Bandung, Jawa Barat 40132, Indonesia
}

\author{
$3^{\text {rd }} \mathrm{R}$ U Mega \\ Departemen Sastra Inggris \\ Universitas Komputer Indonesia \\ J1. Dipati Ukur No.112-116, \\ Lebakgede, Kecamatan Coblong, Kota \\ Bandung, Jawa Barat 40132, Indonesia \\ kota Jakarta 12520, Indonesia \\ raiswati.63718014@mahasiswa.unikom \\ .ac.id
}

\begin{abstract}
This study aims to design a learning system based on Islamic religious education. The method used in this study is a survey method using a questionnaire and observation method as a technique of collecting data about the Islamic learning system. The questionnaire was distributed to 20 respondents. The results of this study are the creation of an e-learning application to study Islamic religion an application that facilitate the process of teaching Islamic religious education by providing references book. The application also provides evaluations for the users. The conclusion of this study is that this Islamic learning application can make people easier to learn Islam.
\end{abstract}

\section{Keywords-Application, Islamic, Online Learning}

\section{INTRODUCTION}

Technology and capabilities of mobile devices' interest are increasing especially in learning through mobile devices [1]. According to Risti and Fadlillah, elearning can provide facilities to the teachers so it is easier to deliver the material and is a fast and practical learning method [2]. Moreover, the religious teacher has revealed that he used cell phones as one of the learning media, and he is also ready to uses cell phones as media learning [3].

E-learning is another way to learn something through mobile devices using internet connection. The internet connection is to facilitate e-learning design application [4], E-learning provides facilities to teachers to make it easier to deliver the material. [5]. Whereas Putri et al also described that the average score in science subjects increased after using e-learning media compared to before [6]. The annual growth rate of e-learning has an average of $16 \%$ of the results from Tibana et al's research, with an increase in annual growth of $3.9 \%$ [7]. In addition about the teacher's response regarding online learning is that the teachers are all satisfied with the benefits of using technology to study. [8]. Eom and Ashill stated that there are six Critical Success Factor(CSF) in order to be success in using e-learning as a method to study namely the quality of design, teacher, motivation, dialogue between students, dialogue between teachers and student, and learn independently, as well as the results of learning [9]. Therefore, Özpolat and Akar stated that the characteristics of e-learning that must be exist is an ability to provide correct information and accordance with the needed according to their choice [10]. However, unfortunately, there is no a research regarding Islamic learning application specifically. Therefore, this study will explaig the Islamic learning application.

This study aims to design a learning system based on Islamic religious education. The method used in this study is a survey method using a questionnaire and observation method as a technique of collecting data about the Islamic learning system. The questionnaire was distributed to 20 people.

\section{METHOD}

The method used in this study was a descriptive qualitative method. Whereas, the data was taken from study literature. This study also used slovin method to take the data from 100 respondents.

\section{RESULTS AND DISCUSSION}

\section{A. Analysis of data}

The data needed to make Islamic Learning applications are learning material data, books for learning, clerics or teachers as instructors information about learning such as assessment problems and statistical data.other than that, information about learning material is also needed such as the books used, teachers, problems with learning activities, learning evaluation information, class ranking information, and diploma online information.

\section{B. Analysis of actor}

There are six actors needed in this Islamic learning system. The first is the admin as the system manager, the user data manager, and the manager for the exam. The second is students as users who access classes, materials, examinations, purchase books, discussions, and see the results of the exam. The third is the teacher or cleric as a 
user who provides material and gives questions for the exam to the admin. The fourth is the Islamic learning database as data storage from the system. The fifth ithe $\mathrm{s}$ Google Play Store as an access for users to download the application on the Google Play Store. The last is Gmail, for the users who forget the password will receive the notification through gmail to get their new passwords.

C. Use case diagram

Activities carried out by users related to the system that produces information about the access rights of each user are described through the use case diagram (See Figure 1).

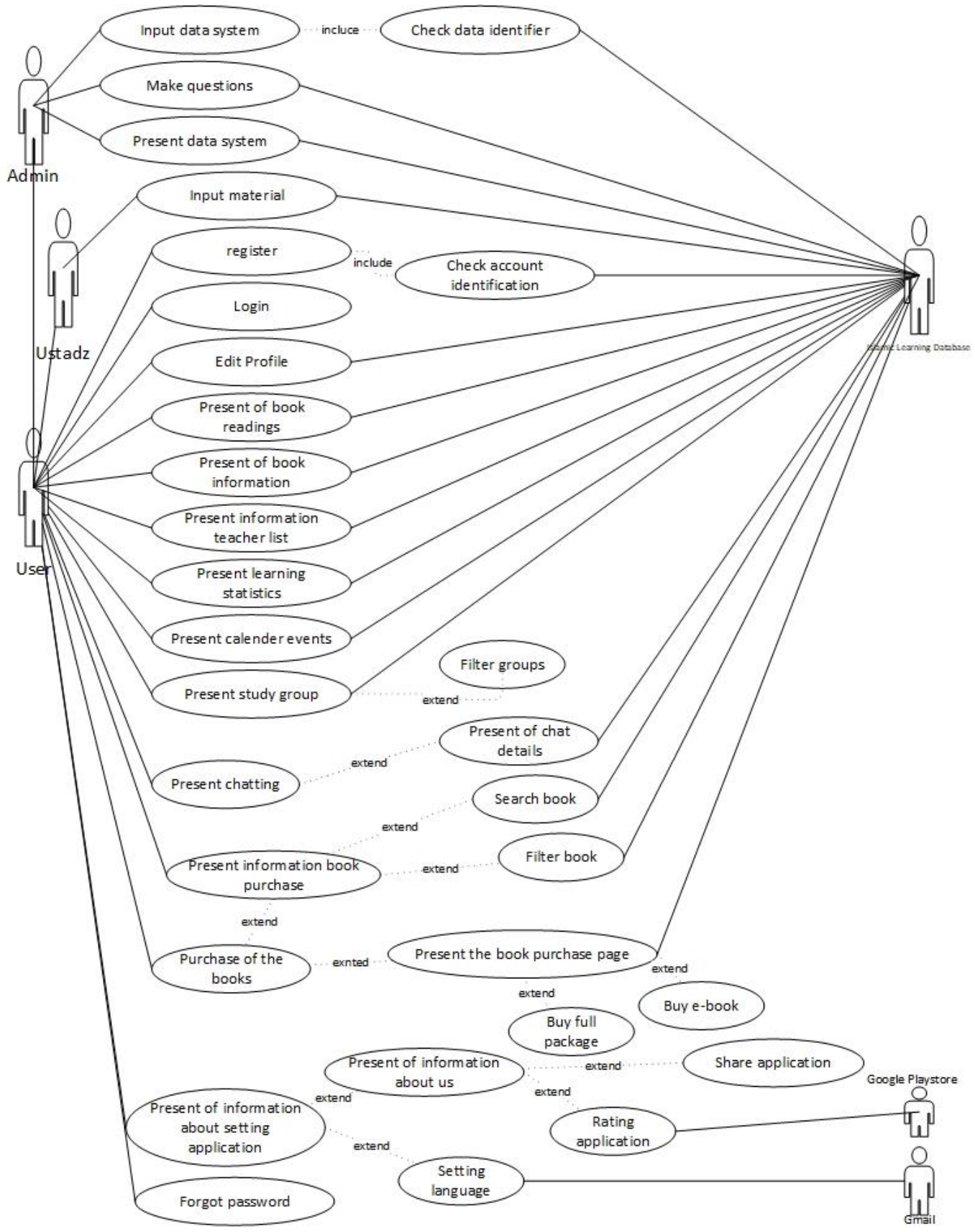

Fig. 1. Use Case Diagram of Islamic Learning Online

In the figure 1 shows the use case of an Islamic learning application, where the use case will be used for the application. After making the use case diagram, the next step is to forward the data that have been found to the class diagram by adding methods to each class. Determining the relationship between each class and other classes could be seen in Figure 2. 


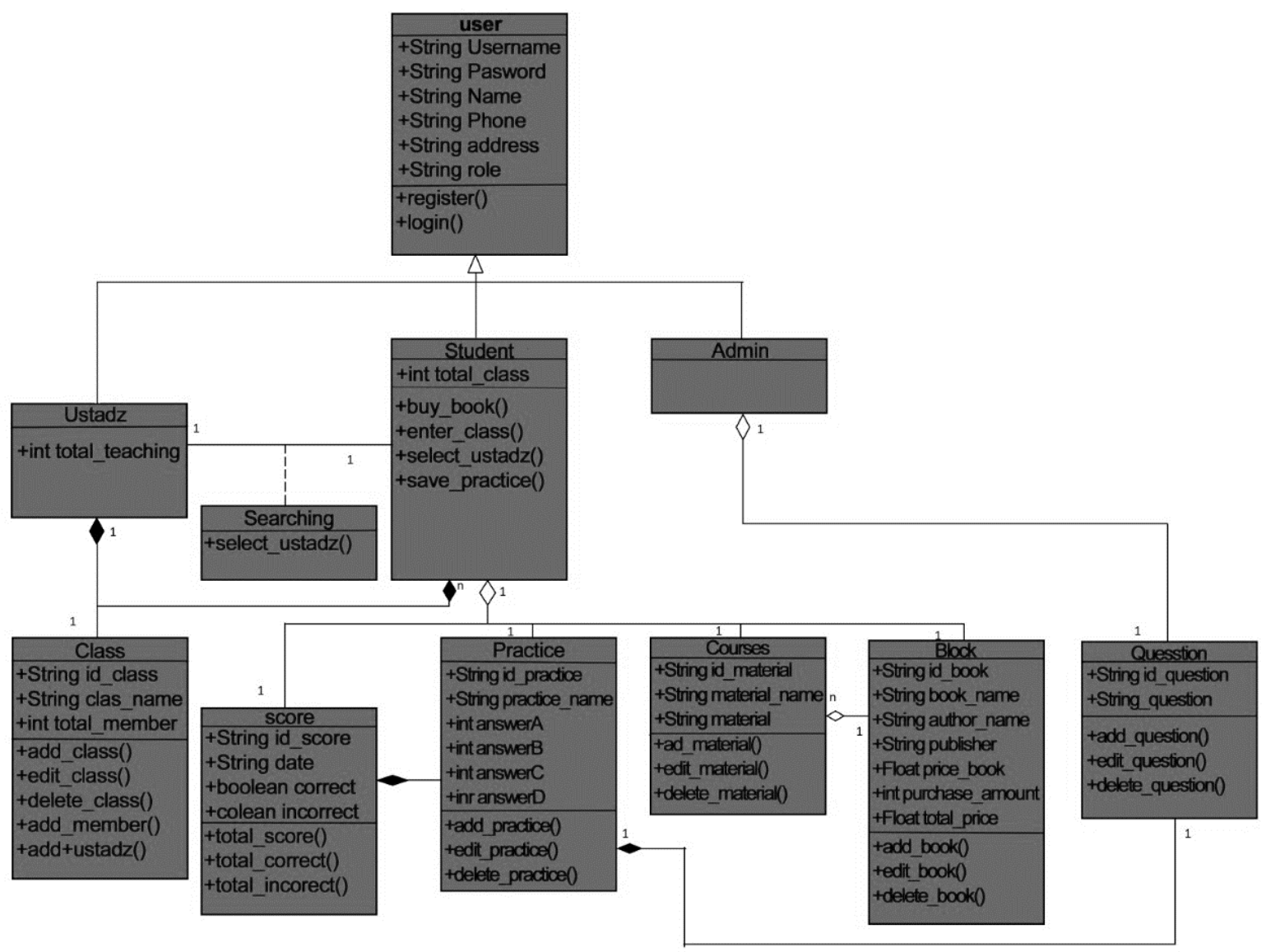

Fig. 2. Class Diagram of Islamic Learning Online

Figure 2 shows the class diagram that will be used in designing this Islamic learning application.

\section{Display Interface Design}

The main access for the teacher is the rights to upload the material, open the chat feature, and open the book reading feature. As for the students, they can buy books, read books that have been purchased and downloaded it, enter the classes, enter discussion forums, enter the book listing page in the store, and enter the list page of passed classes, and go to the exam page (See Figure 3).

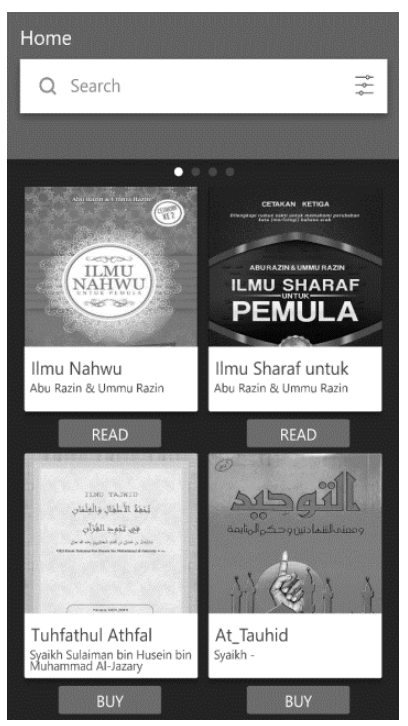

(a)

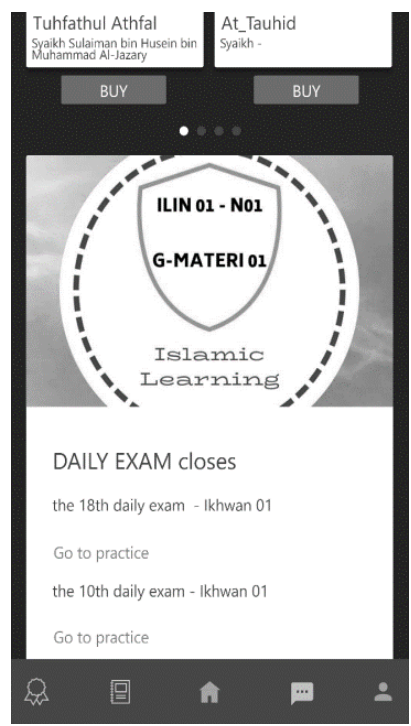

(b)

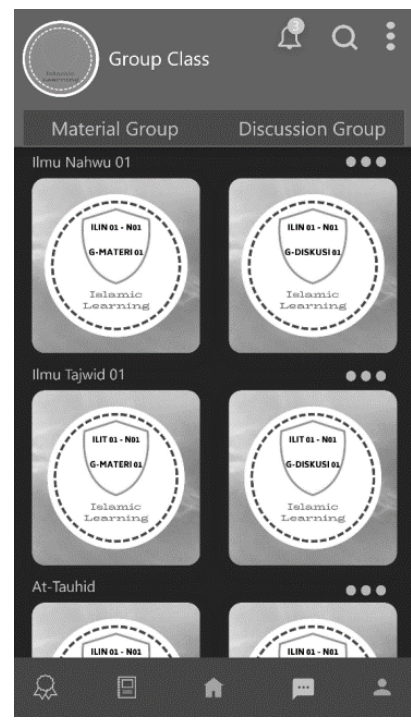

(c)

Fig. 3. Home Form 
The main page for the students can be seen in Figure 3. However, if the students do not have a class, they will be directed to the book store and see the book list page that has been provided, students also can download the purchased e-book, and the students will enter the class according to the book chosen. Then, students can enter the class list page according to their choices. From the class page, you can go to the material class page, go to the discussion page, and to the test page. The material class contains the material provided by the teacher, while in the discussion class contains discussion material for students (See Figure 4).

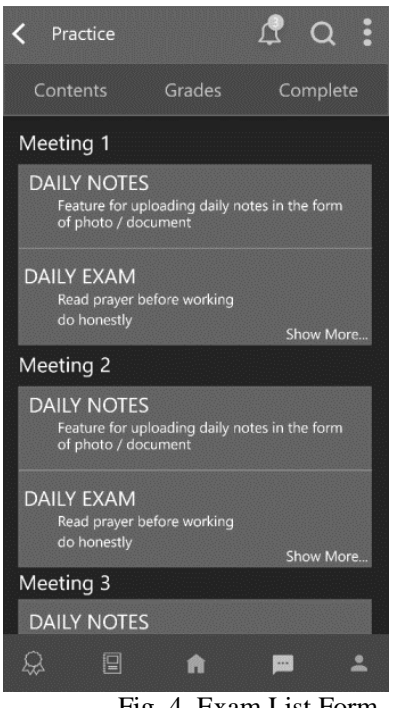

Then from the exam list page, students can send notes, photos, or documents that have been made. Students can work on tests that have been activated by the system. Daily, weekly, and monthly exams are provided in this application.

\section{CONCLUSION}

The main factor to design Islamic learning applications is to know the characteristics of the user and admin, as well as book references that must be used so that the system designed will be run correctly and smoothly so the users are not confused and not bored. However, the main feature of this application is that users can study Islamic religion anywhere with the help oteachersrs and references book, so the students can understand the material better.

\section{ACKNOWLEDGMENT}

We express our gratitude to Rector of Universitas Komputer Indonesia for the support in conducting this research.

\section{REFERENCES}

[1] Sarrab, M., Alzahrani, A., Alwan, N. A., \& Alfarraj, O. (2014). From traditional learning into mobile learning in education at the university level: undergraduate students perspective. International Journal of Mobile Learning and Organisation, 8(34), 167-186.

[2] Fadlilah, U. (2015). Rancang Bangun Website dan E-Learning di TPQ Al-Fadhillah. Khazanah Informatika: Jurnal Ilmu Komputer dan Informatika, 1(1), 40-43.

[3] Nawi, A., Hamzah, M. I., \& Rahim, A. A. (2015). Teachers Acceptance of Mobile Learning for Teaching and Learning in Islamic Education: A Preliminary Study. Turkish Online Journal of Distance Education, 16(1), 184-192.
[4] Magdalene, R., \& Sridharan, D. (2018). Powering E-Learning through Technology: An Overview Of Recent Trends In Educational Technologies. The Online Journal of Distance Education and e-Learning, 6(1), 60.

[5] Cheng, S., \& Siow, H. L. (2018). The Impact of Mobile Technology on the Learning of Management Science and the Development of Problem-Solving Skills. In Innovations in Open and Flexible Education (pp. 133-139). Springer, Singapore.

[6] Putri, N. W. M. A., Jampel, I. N., \& Suartama, I. K. (2014). Pengembangan E-Learning Berbasis Schoology pada Mata Pelajaran IPA Kelas VIII di SMP Negeri 1 Seririt. Jurnal EDUTECH Undiksha, 2(1)

[7] Tibaná-Herrera, G., Fernández-Bajón, M. T., \& de MoyaAnegón, F. (2018). Global analysis of the E-learning scientific domain: a declining category?. Scientometrics, 114(2), 675-685.

[8] Yanti, H., \& Setiawan, A. (2018, February). Teacher's Perception about the Use of E-Learning/Edmodo in Educational Activities. In IOP Conference Series: Materials Science and Engineering (Vol. 306, No. 1, p. 012055). IOP Publishing.

[9] Eom, S. B., \& Ashill, N. J. (2018). A System's View of ELearning Success Model. Decision Sciences Journal of Innovative Education, 16(1), 42-76.

[10] Özpolat, E., \& Akar, G. B. (2009). Automatic detection of learning styles for an e-learning system. Computers \& Education, 53(2), 355-367. 